\title{
SISTEM IDENTIFIKASI BATIK ALAMI DAN BATIK SINTETIS BERDASARKAN KARAKTERISTIK WARNA CITRA DENGAN METODE K-MEANS CLUSTERING
}

\author{
Citra Nurina Prabiantissa ${ }^{1}$, Ariadi Retno Tri Hayati Ririd ${ }^{2}$, Rosa Andrie Asmara ${ }^{3}$ \\ Program Studi Teknik Informatika, Jurusan Teknologi Informasi, Politeknik Negeri Malang ${ }^{1}$ \\ ${ }^{1}$ citranurina@gmail.com, ${ }^{2}$ faniri4education@gmail.com, ${ }^{3}$ rosaandrie@gmail.com
}

\begin{abstract}
Abstrak
Batik adalah kain khas Indonesia yang memiliki berbagai motif dan warna. Pewarnaan batik dibagi menjadi 2 yaitu batik alami dan batik sintetis. Proses pemilihan batik alami dan sintetis umumnya sangat bergantung pada persepsi manusia terhadap komposisi warna. Produsen batik melakukan pengamatan visual secara langsung untuk membedakan warnanya. Kelemahan dari cara ini yaitu keterbatasan visual manusia dan tingkat kelelahan sehingga warna satu dan lainnya dapat tertukar.

Perkembangan ilmu pengetahuan dan teknologi pengolahan citra digital memungkinkan untuk membedakan batik alami dan sintetis secara otomatis dengan bantuan aplikasi pengolahan citra. Identifikasi batik alami dan sintetis ini menerapkan metode K-Means Clustering. Pendukung identifikasi menggunakan bantuan media camera digital sebagai pengambilan gambar batik yang kemudian dihitung nilai normalisasi RGB. Tingkat keberhasilan identifikasi yang didapatkan dengan menggunakan metode $\mathrm{K}$-Means adalah $92.8 \%$. Dari hasil identifikasi yang diperoleh menghasilkan 2 output yaitu Batik Alami $100 \%$ dan Batik Sintetis $85.71 \%$.
\end{abstract}

Kata kunci : Batik, Normalisasi RGB, K-Means Clustering

\section{Pendahuluan}

Batik adalah kain khas Indonesia yang tiap daerahnya memiliki perbedaan. Tiap daerah memiliki perbedaan pada motif, warna, dan tekstur kain. Untuk membuat batik dapat digunakan 2 cara, yaitu secara tradisional (dengan menggunakan canting) dan secara modern (menggunakan mesin). Pembuatan batik dengan cara tradisional membutuhkan waktu yang relatif lama dan membutuhkan ketelitian dari pembuatnya. Sedangkan cara modern yang membutuhkan waktu yang relatif lebih singkat karena pembuatan pola serta pewarnaan menggunakan mesin.

Pewarnaan batik dibedakan menjadi 2, batik alami yaitu batik yang pewarnaannya menggunakan bahan alami dan batik sintetis yaitu batik yang pewanaannya menggunakan bahan kimia. Batik Tulis Sumbersari Bondowoso merupakan sentra batik yang setiap harinya memproduksi berbagai macam batik. Selain proses produksi, terdapat proses sortir terhadap jenis warna yaitu Batik Alami dan Batik Sintetis. Proses sortir batik alami dan sintetis umumnya sangat bergantung pada persepsi manusia terhadap komposisi warna. Produsen batik melakukan pengamatan visual secara langsung untuk membedakan warnanya. Kelemahan dari cara ini yaitu keterbatasan visual manusia dan tingkat kelelahan sehingga warna satu dan lainnya dapat tertukar. Oleh karena itu, diperlukan sistem yang dapat membantu proses sortir batik sesuai dengan jenis warna dari batik.

Pengolahan Citra Digital yang semakin berkembang saat ini menyediakan kemungkinan manusia membuat sistem untuk mengenali suatu gambar atau citra digital. Pengolahan citra merupakan salah satu jenis teknologi untuk menyelesaikan masalah mengenai pemrosesan gambar. Dalam pengolahan citra, gambar dapat diolah sedemikian rupa sehingga gambar tersebut dapat digunakan untuk identifikasi. Dengan bantuan kamera digital, komputer dan pengolahan citra digital sederhana, sistem tersebut dapat terealisasi sehingga proses identifikasi batik dapat dilakukan dengan cepat dan memperoleh hasil yang akurat.

\section{Landasan Teori}

\subsection{Batik}

Batik merupakan salah satu warisan nusantara yang unik. Keunikannya ditunjukkan dengan barbagai macam motif dan warna yang memiliki makna tersendiri. Menurut Asti M. dan Ambar B. Arini (2011: 1) berdasarkan etimologi dan terminologinya, batik merupakan rangkaian kata mbat dan tik. Mbat dalam bahasa Jawa dapat 
diartikan sebagai ngembat atau melempar berkalikali, sedangkan tik berasal dari kata titik. Jadi, membatik artinya melempar titik berkali-kali pada kain.

\subsection{Pengolahan Citra}

Pengolahan citra merupakan proses pengolahan dan analisis citra yang banyak melibatkan persepsi visual. Proses ini mempunyai ciri data masukan dan informasi keluaran yang berbentuk citra. Istilah pengolahan citra digital secara umum didefinisikan sebagai pemrosesan citra dua dimensi dengan komputer. (D. Putra,2010)

\subsection{Citra Digital}

Citra Digital adalah representasi, kemiripan, atau imitasi dari suatu objek. Citra sebagai keluaran suatu sistem perekaman data dapat bersifat optic berupa foto, bersifat analog berupa sinyal-sinyal video seperti gambar pada monitor televisi, atau bersifat digital yang dapat langsung disimpan pada suatu media penyimpanan. (Sutoyo, 2009)

\subsection{Normalisasi RGB (Red, Green, Blue)}

Normalisasi RGB sering disebut dengan warna murni. Proses normalisasi RGB merupakan proses pengubahan nilai RGB dalam range 0 sampai 1 yang dibentuk secara independen dari berbagai tingkat pencahayaan. Jumlah dari nilai red, green dan blue channel yang telah dinormalisasi adalah 1. Ketiga channel yang telah dinormalisasi tersebut tidak memiliki informasi yang signifikan dan dapat diabaikan, sehingga dapat mengurangi dimensi ruang. Proses normalisasi RGB dilakukan dengan persamaan 2.9 sampai 2.11 (Ennehar, et al., 2010)

$$
R^{\prime}=\frac{R}{R+G+B}
$$

$$
G^{\prime}=\frac{G}{R+G+B}
$$

$$
\text { (2) }
$$

$$
B^{\prime}=\frac{B}{R+G+B}
$$

Dimana :

$$
\begin{aligned}
& \mathrm{R}^{\prime}=\text { nilai red channel yang telah dinormalisasi } \\
& \text { pada piksel } \\
& \mathrm{G}^{\prime}=\text { nilai green channel yang telah dinormalisasi } \\
& \quad \text { pada piksel }
\end{aligned}
$$

B' = nilai blue channel yang telah dinormalisasi pada piksel

\subsection{Clustering}

Clustering adalah suatu metode untuk mengelompokkan dokumen dimana dokumen dikelompokkan dengan konten untuk mengurangi ruang pencarian yang diperlukan dalam merespon suatu query. Misalnya koleksi dokumen yang berisi dokumen-dokumen medis dan hokum dapat dikelompokkan sedemikian rupa sehingga semua dokumen medis ditempatkan dalam satu cluster dan semua dokumen hokum ditempatkan dalam satu cluster hokum. (Grossman, David A. dan Ophir Frieder, 2004)

\subsection{Algoritma K-Means Clustering}

Menurut Adiningsih (2007), tahap penyelesaian algoritma K-Means adalah sebagai berikut:

a. Menentukan $K$ buah titik yang merepresentasikan obyek pada setiap cluster (centroid awal).

b. Menetapkan setiap objek pada cluster dengan posisi centroid terdekat.

c. Jika semua objek sudah dikelompokkan maka dilakukan perhitungan ulang dalam menentukan centroid yang baru.

d. Ulangi langkah ke-2 dan ke-3 sampai centroid tidak berubah.

\section{Metodologi Penelitian}

\subsection{Metodologi}

Metode pembuatan perangkat lunak ini adalah dengan menggunakan metode Waterfall. Menurut Sommerville (2011:29) Waterfall model mengambil kegiatan proses dasar spesifikasi, pengembangan, validasi, dan evolusi dan mewakili kegiatan tersebut sebagai fase terpisah seperti spesifikasi persyaratan, perancangan perangkat lunak, implementasi, pengujian dan sebagainya. Adapun tahap dalam metode waterfall ini adalah sebagai berikut:

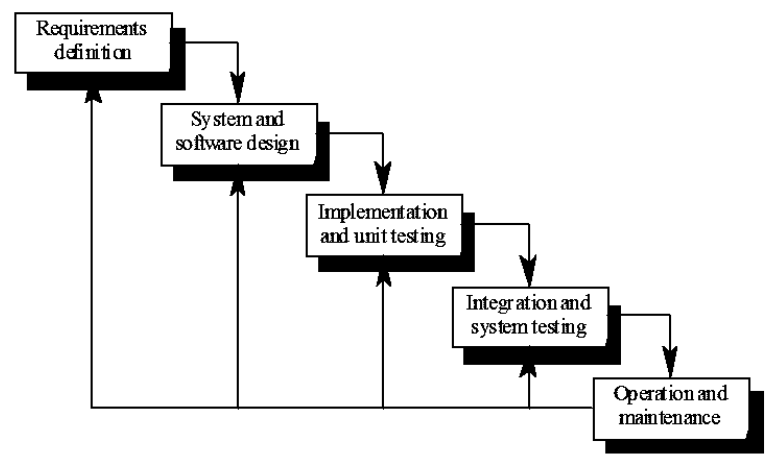

Gambar 1. Metode Waterfall 


\subsection{Data Sistem}

Komponen yang diperlukan untuk melakukan penelitian salah satunya adalah data. Data yang diperlukan sebagai objek pengujian sistem identifikasi batik alami dan buatan berdasarkan karakteristik warna citra dengan metode $K$-Means Clustering adalah batik alami dan batik sintetis yang memiliki komposisi warna yang satu dan lainnya berbeda. Serta image atau citra yang didapat dari data sampel batik alami dan batik sintetis. Berikut ini adalah contoh data citra batik alami :

a. Batik yang menggunakan pewarna alami dari kulit pohon Jambal (Pelthopherum pterocarpum) dan Tingi (Ceriops condolleana)

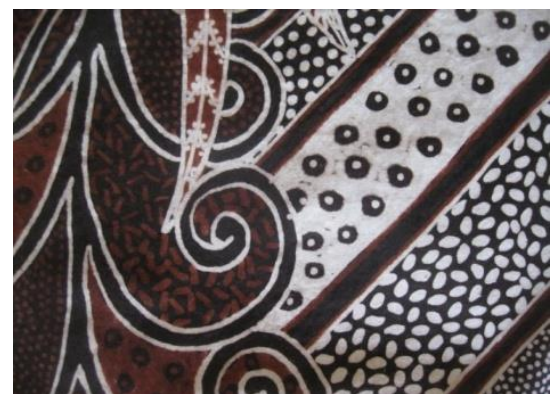

Gambar 2. Batik yang terbuat dari kulit pohon Jambal dan Tingi

b. Batik menggunakan pewarna alami dari dari kulit pohon Tingi (Ceriops condolleana)

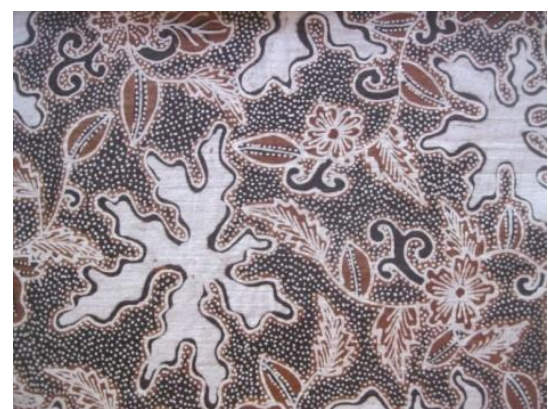

Gambar 3. Batik yang terbuat dari kulit pohon Tingi

c. Batik yang menggunakan pewarna alami dari tanaman perdu Indigo atau (Indigofera L) dan tanaman jalawe (Terminalia Belerica)

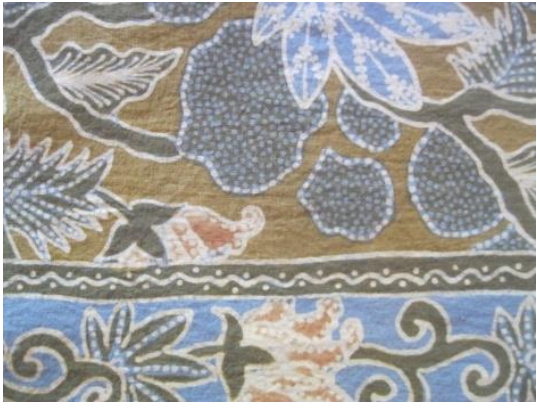

Gambar 4. Batik yang menggunakan pewarna dari tanaman indigo dan jalawe

Berikut ini adalah contoh data citra batik sintetis :

a. Batik yang dibuat dengan pewarna sintetis naphtol dan indigosol

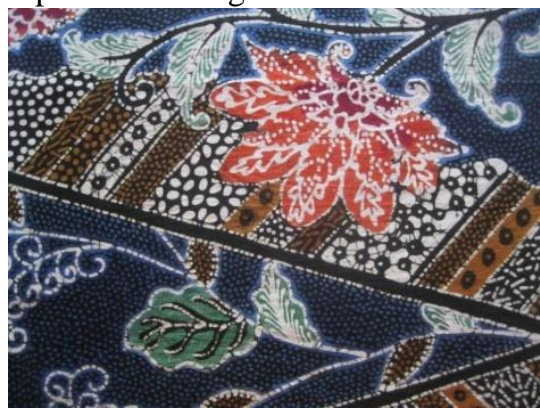

Gambar 5. Batik yang menggunakan pewarna sintetis napthol dan indigosol

b. Batik yang dibuat dengan pewarna sintetis aerosol

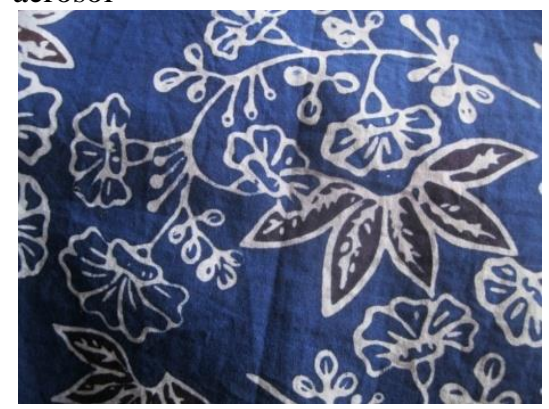

Gambar 6. Batik yang menggunakan pewarna sintetis aerosol

\section{Analisis dan Perancangan}

\subsection{Analisis Sistem}

Analisis sistem merupakan suatu penjabaran mengenai komponen - komponen penyusun sistem dalam penelitian ini baik perangkat lunak maupun perangkat keras. Serta gambaran umum sistem yang akan berjalan.

Proses yang terdapat dalam aplikasi ini adalah proses training dan proses testing. Dimana proses training berfungsi untuk pengolahan gambar agar dapat diidentifikasi. Sedangkan proses testing untuk mengidentifikasi batik alami dan buatan dengan menggunakan metode K-Means Clustering. 


\subsection{Perancangan Sistem}

Pada perancangan proses untuk sistem identifikasi batik alami dan sintetis akan disajikan ke dalam bentuk Flowchart menggunakan metode K-Means Clustering. Sistem Identifikasi Batik dibagi menjadi 2, yaitu Proses Training dan Proses Testing:

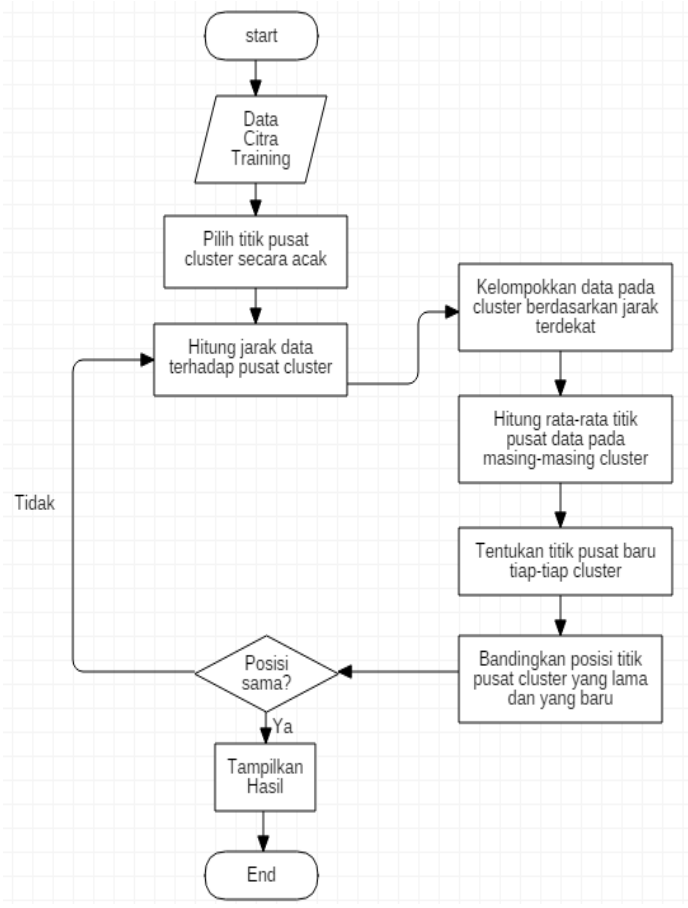

Gambar 7. Proses Training

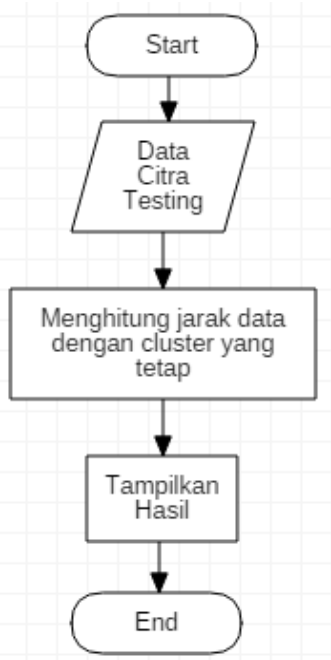

Gambar 8. Proses Testing

\section{IMPLEMENTASI}

Dalam sistem identifikasi ini terdapat 2 proses yaitu proses traning dan proses testing. Dimana proses traning digunakan untuk menghitung dan melatih data citra batik yang sudah disimpan. Proses testing digunakan untuk menguji data citra baru sesuai dengan pusat cluster yang tidak berubah (tetap) pada proses training sebelumnya. Berikut adalah interface dari proses traning dan proses testing :

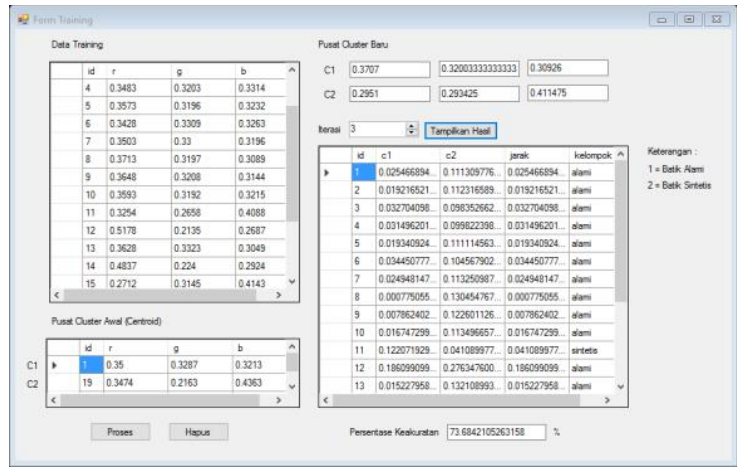

Gambar 9. Form Training

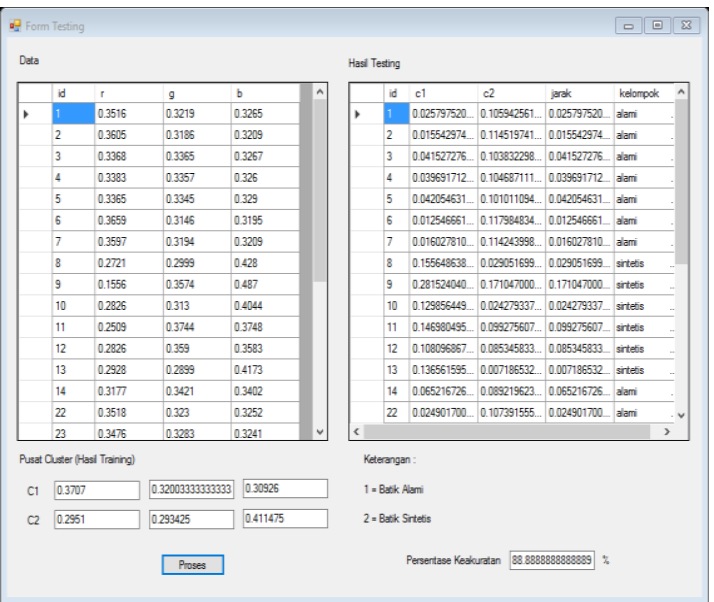

Gambar 10. Form Testing

\section{PENGUJIAN DAN PEMBAHASAN}

\subsection{Pengujian Proses}

Pengujian merupakan cara atau teknik untuk menguji perangkat lunak, mempunyai mekanisme untuk menentukan data uji yang dapat menguji perangkat lunak secara lengkap dan mempunyai kemungkinan tinggi untuk menemukan kesalahan. Berikut dibawah merupakan pengujian yang dilakukan di dalam sistem identifikasi batik alami dan sintetis berdasarkan karakteristik warna citra :

a) Pengujian Blackbox atau Fungsional

Pengujian ini dilakukan untuk menemukan fungsi-fungsi yang tidak benar atau hilang, kesalahan interface, kesalahan dalam struktur data atau akses database eksternal, kesalahan kinerja, inisialisasi dan kesalahan terminasi. Pengujian fungsi-fungsi pada sistem identifikasi batik alami dan sintetis telah berjalan dengan baik. 
Tabel 1. Pengujian Blackbox

\begin{tabular}{|c|c|c|c|c|c|}
\hline No & $\begin{array}{l}\text { Pola } \\
\text { Peng } \\
\text { ujian } \\
\end{array}$ & $\begin{array}{c}\text { Data } \\
\text { Input }\end{array}$ & Validasi & $\begin{array}{l}\text { Hasi } \\
\text { I Uji }\end{array}$ & $\begin{array}{c}\text { Status } \\
\text { Uji }\end{array}$ \\
\hline 1. & $\begin{array}{l}\text { Input } \\
\text { Data } \\
\text { (Data } \\
\text { Baru) } \\
\text { Pada } \\
\text { Form } \\
\text { Data } \\
\text { Citra }\end{array}$ & $\begin{array}{l}\text { Normalisa } \\
\text { si Red, } \\
\text { Normalisa } \\
\text { si Green, } \\
\text { Normalisa } \\
\text { si Blue }\end{array}$ & $\begin{array}{l}\text { Data } \\
\text { Tidak } \\
\text { Valid }\end{array}$ & $\begin{array}{l}\text { Data } \\
\text { tersi } \\
\text { mpa } \\
\text { n di } \\
\text { datab } \\
\text { ase }\end{array}$ & Berhasil \\
\hline 2. & $\begin{array}{l}\text { Tamp } \\
\text { il } \\
\text { Data } \\
\text { Pada } \\
\text { Form } \\
\text { Data } \\
\text { Citra }\end{array}$ & $\begin{array}{l}\text { Normalisa } \\
\text { si Red, } \\
\text { Normalisa } \\
\text { si Green, } \\
\text { Normalisa } \\
\text { si Blue }\end{array}$ & $\begin{array}{l}\text { Data } \\
\text { diambil } \\
\text { dari } \\
\text { database }\end{array}$ & $\begin{array}{l}\text { Data } \\
\text { berh } \\
\text { asil } \\
\text { tamp } \\
\text { il }\end{array}$ & Berhasil \\
\hline 3. & $\begin{array}{l}\text { Hapu } \\
\text { s Data } \\
\text { Pada } \\
\text { Form } \\
\text { Data } \\
\text { Citra }\end{array}$ & $\begin{array}{l}\text { Normalisa } \\
\text { si Red, } \\
\text { Normalisa } \\
\text { si Green, } \\
\text { Normalisa } \\
\text { si Blue }\end{array}$ & $\begin{array}{l}\text { Tombol } \\
\text { hapus di } \\
\text { klik }\end{array}$ & $\begin{array}{l}\text { Data } \\
\text { berh } \\
\text { asil } \\
\text { diha } \\
\text { pus }\end{array}$ & Berhasil \\
\hline 4. & $\begin{array}{l}\text { Simp } \\
\text { an } \\
\text { data } \\
\text { inisial } \\
\text { isasi } \\
\text { dari } \\
\text { Form } \\
\mathrm{K}- \\
\text { Mean } \\
\text { s ke } \\
\text { datab } \\
\text { ase } \\
\end{array}$ & $\begin{array}{l}\mathrm{C} 1, \mathrm{C} 2, \\
\text { jarak, dan } \\
\text { kelompok }\end{array}$ & $\begin{array}{l}\text { Tombol } \\
\text { Proses di } \\
\text { klik }\end{array}$ & $\begin{array}{l}\text { Data } \\
\text { berh } \\
\text { asil } \\
\text { di } \\
\text { simp } \\
\text { an }\end{array}$ & Berhasil \\
\hline 5. & $\begin{array}{l}\text { Hapu } \\
\text { s } \\
\text { cluste } \\
\mathrm{r} \text { acak } \\
\text { pada } \\
\text { Form } \\
\text { K- } \\
\text { Mean } \\
\text { s } \\
\end{array}$ & $\begin{array}{l}\text { Normalisa } \\
\text { si Red, } \\
\text { Normalisa } \\
\text { si Green, } \\
\text { Normalisa } \\
\text { si Blue }\end{array}$ & $\begin{array}{l}\text { Tombol } \\
\text { Hapus di } \\
\text { klik }\end{array}$ & $\begin{array}{l}\text { Data } \\
\text { berh } \\
\text { asil } \\
\text { di } \\
\text { hapu } \\
\text { s }\end{array}$ & Berhasil \\
\hline
\end{tabular}

\section{b) Pengujian Akurasi}

Uji coba ini dilakukan untuk menguji akurasi sistem dengan menghitung prosentase data benar dari pusat cluster yang berbeda-beda. Parameter yang digunakan yaitu normalisasi R , G ,B. Dalam pengujian ini diperlukan sebanyak 14 data batik terdiri dari :
Tabel 2. Pengujian Tingkat Keakurasian

\begin{tabular}{|c|c|c|c|c|}
\hline $\begin{array}{c}\text { Jenis } \\
\text { Batik }\end{array}$ & $\begin{array}{c}\text { Jumlah } \\
\text { Sampel }\end{array}$ & Sesuai & $\begin{array}{c}\text { Tidak } \\
\text { Sesuai }\end{array}$ & $\begin{array}{c}\text { Tingkat } \\
\text { Akurasi }\end{array}$ \\
\hline $\begin{array}{c}\text { Batik } \\
\text { Alami }\end{array}$ & 7 & 7 & 0 & $100 \%$ \\
\hline $\begin{array}{c}\text { Batik } \\
\text { Sintetis }\end{array}$ & 7 & 6 & 1 & $85.71 \%$ \\
\hline
\end{tabular}

\subsection{Analisa Hasil Penelitian}

Dari hasil identifikasi terbaik yang dilakukan tentang keakuratan sistem didapatkan tingkat keberhasilan sistem identifikasi batik alami dan batik sintetis berdasarkan karakteristik warna citra dengan metode K-Means Clustering adalah $100 \%$ untuk batik alami dan $85.71 \%$ untuk batik sintetis. Data batik alami lebih banyak dapat diidentifikasi oleh sistem daripada batik sintetis. Hal ini dikarenakan warna batik sintetis yang menyerupai warna dari batik alami sehingga sistem sulit untuk membedakan keduanya. Serta pencahayaan dan keterbatasan kemampuan kamera pada saat pengambilan data.

Dari keseluruhan data yaitu 14 data batik hasil pengujian, maka didapatkan tingkat akurasi sebagai berikut :

$$
\begin{gathered}
\text { Persentase Keakuratan }=\frac{13}{14} \times 100 \% \\
=92.85 \%
\end{gathered}
$$

Tingkat keberhasilan secara keseluruhan yaitu $92.8 \%$.

\section{Kesimpulan}

\subsection{Kesimpulan}

Berdasarkan hasil dari penelitian yang dilakukan dapat diambil beberapa kesimpulan sebagai berikut :

1. Aplikasi masih jauh dari sempurna, sebagai acuan untuk penelitian lebih lanjut

2. Sistem Identifikasi batik alami dan batik sintetis dengan mengimplementasikan metode K-Means Clustering memperoleh tingkat keberhasilan identifikasi sebesar $92.8 \%$

3. Dari hasil identifikasi dengan menggunakan metode $K$-Means Clustering yang diperoleh yaitu menghasilkan 2 output yaitu batik alami sebesar $100 \%$ dan batik sintetis sebesar $85.71 \%$

4. Hasil cluster dipengaruhi dari nilai centroid awal yang dipakai dan jumlah data yang dipakai. Perbedaan pengambilan data pusat centroid awal yang dipakai juga 
akan mempengaruhi hasil centroid akhirnya.

5. Pengelompokan citra batik alami dan sintetis bergantung pada teknik pengambilan gambar yaitu merk dan tipe kamera, resolusi kamera, resolusi gambar yang digunakan, jarak pengambilan gambar, dan pencahayaan. Teknik pengambilan gambar yang berbeda mengakibatkan hasil pengelompokan yang berbeda pula.

6. Identifikasi batik alami dan batik sintetis menggunakan metode K-Means Clustering banyak mendeteksi batik alami daripada batik sintetis dikarenakan warna batik sintetis yang menyerupai warna dari batik alami sehingga sistem terkadang tertukar. Hal tersebut dapat terjadi karena nilai normalisasi RGB batik alami mirip dengan nilai normalisasi RGB batik sintetis.

\subsection{Saran}

Saran yang ditujukan untuk pengembangan penelitian ini adalah :

1. Diharapkan dengan pengembangan sistem identifikasi batik alami dan batik sintetis dapat menambah spesifikasi media seperti kamera digital dengan resolusi yang lebih baik sehingga kadar warna pada kain dengan gambar yang diambil sama sehingga terdapat perbedaan warna yang lebih jelas.

2. Pada pengembangan aplikasi selanjutnya diharapkan dapat menambah parameter yang digunakan untuk membedakan data satu dengan yang lain seperti menggunakan nilai HSV (Hue Saturation Value) dan menggunakan Histogram.

\section{Daftar Pustaka :}

Adiningsih, N. 2007. Penggunaan K-Means Clustering untuk Pelabelan Fonem Sinyal Ucapan. Institut Teknologi Bandung. Bandung.

Adnan, dkk. 2013. Identifikasi Varietas Berdasarkan Warna dan Tekstur Permukaan Beras Menggunakan Pengolahan Citra Digital dan Jaringan Syaraf Tiruan. Balai Pengkajian Tekologi Pertanian. Papua.

Alifah, Henny. 2014. Membuat Atau Menulis Daftar Pustaka. [Online] Tersedia : http://www.satujam.com/membuat-ataumenulis-daftar-pustaka/ [29 Mei 2016]

Andri, dkk. 2014. Segmentasi Buah Menggunakan Metode K-Means Clustering dan Identifikasi Kematangannya Menggunakan Metode Perbandingan Kadar Warna.STMIK Mikroskil.

Grossman, David A. dan Ophir Frieder, 2004. Information Retrieval Algorithms and
Heuristics Second Edition.Springer, The Netherlands.

Handoko, Agus Purwo dan Yustina Retno Wahyu Utami, 2009. Pengenalan Buah Berdasarkan Karakteristik Warna Citra.

Kusumanto, RD. 2011. Pengolahan Citra Digital Untuk Mendeteksi Obyek Menggunakan Pengolahan Warna Model Normalisasi RGB. Politeknik Negeri Sriwijaya. Palembang.

Lisbijanto, Herry. 2013. Batik. Yogyakarta : Graha Ilmu.

Musman, Asti dan Ambar B. Arini. 2011. Batik Warisan Adiluhung Nusantara. Yogyakarta: G-Media.

Putra D. 2010. Pengolahan Citra Digital. Yogyakarta: Penerbit Andi

Sutoyo, T., Mulyanto, E., Suhartono, V., Nurhayati, D.O., Wijanarto.2009. Teori Pengolahan Citra Digital. Yogyakarta.

Wardani, Eka Widya. "Pengenalam Motif Batik Menggunakan Metode Transformasi Paket Wavelet". Fakultas Teknik. Universitas Widyatama. Bandung 